\title{
Total Phenolics, Flavonoids, Condensed Tannins Content of Eight Centaurea Species and Their Broad Inhibitory Activities against Cholinesterase, Tyrosinase, $\alpha$-Amylase and $\alpha$-Glucosidase
}

\author{
Gokhan ZENGIN ${ }^{1 *}$, Marcello LOCATELLI ${ }^{2,3 * *}$, Simone CARRADORI ${ }^{2}$, \\ Andrei M. MOCAN ${ }^{4}$, Abdurrahman AKTUMSEK ${ }^{1}$
}

\author{
${ }^{1}$ SelcukUniversity, Science Faculty, DepartmentofBiology, Konya, Turkey; gokhanzengin@selcuk.edu.tr("corresponding author); aktumsek@selcuk.edu.tr \\ 2University “G.d'Annunzio" OfChieti-Pescara, DepartmentofPharmacy, 66100, Chieti Italy; m.locatelli@unich.it (*co-correspondingauthor); simone.carradori@unich.it \\ 3Interuniversity Consontium of Structural and SystemsBiology,00136,Rome, Italy; m.locatelli@unich.it \\ 4"Iuliu Hatieganu"University of Medicine and Pharmacy, Department of Pharmaceutical Botany, 8Victor Babes Street, Cluj-Napoca, Romania; mocam.andrei@umfchij.ro
}

\begin{abstract}
Several bioactive compounds originate from natural sources and their uses are generally related with traditional or folk medicine. Synthetic drugs can have adverse side effects and, for this reason, the investigation of novel, safe, and naturaloccurring products can account for the development of new drugs. The genus Centaurea L. is one of the most important genera of the Asteraceae family, containing more than 200 species in the Turkish flora, about 140 of which are endemic. The aim of the present work was to determine enzyme inhibitory potentials of two extracts (chloroform and ethyl acetate) from eight Centaurea species against cholinesterase, tyrosinase, amylase, and glucosidase. The total phenolics, flavonoids and condensed tannin contents were also reported for each extract. These components in the extracts varied according to species and extraction solvents as well as enzyme inhibitory effects. The highest level of phenolics was found to be in the chloroform extract of C. pulchella (119.23 mg GAEs/g extract). Generally, chloroform extracts exhibited stronger enzyme inhibitory effects as compared to ethyl acetate. Additionally, possible correlations with total phenolics, flavonoids, and condensed tannins content were also highlighted. This paper is the first report of the inhibitory capacities of the eight Centaurea species on the selected enzymes. The present results may be a valuable starting point in the development of new bioactive formulations.
\end{abstract}

Keywords: natural products, bioactive compounds, enzyme inhibition, Turkey

\section{Introduction}

Up to date, the search of new biologically active agents from natural sources represents a promising area of investigation. Therefore, a remarkable number of modern drugs (about 40\%) derive from plants well known for their uses in traditional or folk medicine (De Monte et al., 2015). This is rooted in the cumulative evidence that connects synthetic drugs with adverse effects such as carcinogenic, hepatotoxic and gastrointestinal disorders (Pan et al., 2013). Thus, the investigation of novel, safely, and natural-derived products can contribute for the development of new drugs in pharmaceutical areas (Locatelli et al., 2012a; Carradori et al., 2014).

The inhibition of key enzymes is one of the most accepted practices for major health problems including Alzheimer's disease $(\mathrm{AD})$ and Diabetes mellitus (DM). According to the actually used therapy, the "inhibition of key enzymes" approach is an effective way for the treatment and management of these pathologies. For example, cholinesterase inhibitors increase brain acetylcholine levels, thus improving cognitive functions in $\mathrm{AD}$ patients (Mukherjee et al., 2007). Carbohydrate digestive enzymes ( $\alpha$-amylase and $\alpha$-glucosidase) inhibitors are important for the management of blood glucose levels in DM patients (Kumar et al., 2013). Therefore, several synthetic inhibitors are used clinically, but they show limited effectiveness and some side effects (Orhan et al., 2004; Tundis et al., 2012, Gidaro et al., 2015). For these reasons, effort has been made in order to screen and develop new inhibitors from natural sources with high efficacy and reduced side effects.

The genus Centaurea $\mathrm{L}$. is one of the most important genera of the Asteraceae family, and is represented by approx. 500 species (Garci-Jacas et al., 2000). Turkey flora gathers more than 200 species of which about 140 are considered endemic (Davis, 1988). Members of Centaurea have been used in Anatolian traditional medicine for the treatment of various ailments such as diarrhea and wound healing (Karamenderes et al., 2006; Shoeb et al., 2007). The uses of these species in traditional medicine is also highlighted by the high number of studies concerning members of this genus (Zengin et al, 2010; Jemia et al., 2012; Aktumsek et al., 2013; Ertas et al., 2014; Maggio et al., 2014). Many bioactive constituents were identified in these plants such as terpenes, phenolics, coumarins and lignans. However, literature is scarce about their enzyme inhibitory effects (only anticholinesterase) (Aktumsek et al., 2013; Ertas et al., 2014).

Continuing our studies (Genovese et al., 2010; Locatelli et al., 2011; Locatelli et al., 2012b; De Monte et al., 2014; Zengin et al., 2015), and the partial information available in literature 
196

regarding these species, the aim of this study was to investigate, for first time, the potential correlation between total bioactive components and biological activities on key enzymes involved in AD, DM (type 2), and skin disorders of eight Centaurea species from Turkish spontaneous flora.

\section{Materials and Methods}

\section{Plant material}

Eight Centaurea species $(1-C$. depressa; 2 - C. drabifolia subsp. detonsa; 3 - C. kotschyi var. persica; 4 - C. patula; 5 - C. pulchella; 6 - C. tchihatcheffi; 7 - C. triumfettii; 8 C. urvillei subsp. hayekiana) were collected from Konya and Ankara (Golbası), in Turkey. The senior taxonomists Dr. Murad Aydın Sanda and Dr. Tuna Uysal from the Department of Biology (Selcuk University), confirmed the taxonomic identification of the raw plant material, and voucher specimens were deposited in the Herbarium of the Department of Biology (Selcuk University, Konya-Turkey).

\section{Preparation of the extracts}

Raw collected materials were air-dried at $45^{\circ} \mathrm{C}\left( \pm 1^{\circ} \mathrm{C}\right)$ for 48 hours in the dark. In this way, as also reported in literature (Anwar et al., 2013; Khoddami et al., 2013) it is possible to obtain the higher phenolics preservation before solvent extraction.

To produce solvent extracts, air-dried samples $(10 \mathrm{~g})$ from the aerial part of Centaurea species were macerated with $200 \mathrm{~mL}$ of ethyl acetate or chloroform at room temperature $\left(25^{\circ} \mathrm{C} \pm 1\right.$ ${ }^{\circ} \mathrm{C}$ ) for $24 \mathrm{~h}$ in the dark, then the solvents were removed to dryness using a rotary evaporator. Extracts obtained using organic solvents were redissolved in methanol and then filtered. All extracts were stored at $-20^{\circ} \mathrm{C}$ until analyses.

\section{Determination of total bioactive components}

\section{Totalphenolics content}

The total phenolics content was determined by employing the methods described in the literature (Slinkard and Singleton, 1977 ) with slight modifications. Sample solutions $(0.25 \mathrm{~mL})$ were mixed with diluted Folin-Ciocâlteu reagent $(1 \mathrm{~mL}, 1: 9, v: v)$ and shaken vigorously. After 3 minutes, $\mathrm{Na}_{2} \mathrm{CO}_{3}$ solution $(0.75$ $\mathrm{mL}, 1 \%)$ was added, and the sample absorbances were read at $760 \mathrm{~nm}$ after 2 hours of incubation, at room temperature (RT, $\left.25^{\circ} \mathrm{C} \pm 1{ }^{\circ} \mathrm{C}\right)$. The total phenolics content was expressed as equivalents of gallic acid (GAEs) according to the equation obtained from the standard gallic acid graph.

\section{Total flavonoids content}

The total flavonoids content was determined using the Dowd method as adapted by Berk et al. (2011). Briefly, the sample solutions $(1 \mathrm{~mL})$ were mixed with the same volume of aluminum trichloride (2\%) in methanol. Similarly, blank samples were prepared by adding sample solutions $(1 \mathrm{~mL})$ to methanol $(1 \mathrm{~mL})$ without $\mathrm{AlCl}_{3}$. The absorbances of samples and blanks were read at $415 \mathrm{~nm}$ after 10 minutes of incubation at RT $\left(25^{\circ} \mathrm{C} \pm 1{ }^{\circ} \mathrm{C}\right)$. The blank sample absorbances were subtracted from the sample, and the total flavonoids content was expressed as equivalents of rutin (REs) according to the equation obtained from the standard rutin graph.

\section{Total condensed tannins content}

The total condensed tannins content was determined by the vanillin method (Bekir et al., 2013) with slight modifications. Sample solutions $(0.5 \mathrm{~mL})$ were mixed with vanillin reagent $(1.5$ $\mathrm{mL}, 1 \%$ in $7 \mathrm{M} \mathrm{H}_{2} \mathrm{SO}_{4}$ ) in an ice bath and then vigorously shaken. Similarly, blank samples were prepared by adding sample solution $(0.5 \mathrm{~mL})$ to $7 \mathrm{M} \mathrm{H}_{2} \mathrm{SO}_{4}(1.5 \mathrm{~mL})$. The sample and blank absorbances were read at $500 \mathrm{~nm}$ after 15 minutes of incubation at $\mathrm{RT}\left(25^{\circ} \mathrm{C} \pm 1^{\circ} \mathrm{C}\right)$. The blank sample absorbances were subtracted from the sample, and the total condensed tannins content was expressed as equivalents of $(+)$-catechin (CEs) according to the equation obtained from the standard (+)-catechin graph.

\section{Enzyme inbibitory activity}

\section{Cholinesterase inbibition}

Cholinesterase (ChE) inhibitory activity was measured using Ellman's method, as previously reported (Aktumsek et al., 2013) with slight modifications. Sample solution $(2 \mathrm{mg} / \mathrm{mL}, 50 \mu \mathrm{L})$ was mixed with 5,5'-dithiobis-(2-nitrobenzoic acid) (DTNB, $125 \mu \mathrm{L})$ and $\mathrm{AChE}$ (or BChE) solution $(0.26 \mathrm{u} / \mathrm{mL}, 25 \mu \mathrm{L})$ in Tris-HCl buffer ( $\mathrm{pH} 8.0)$ in a 96-well microplate and incubated for 15 minutes at $25^{\circ} \mathrm{C}\left( \pm 1^{\circ} \mathrm{C}\right)$. The reaction was started with the addition of acetylthiocholine iodide (ATCI) or butyrylthiocholine chloride (BTCl) $(25 \mu \mathrm{L})$. Similarly, blank sample was prepared by adding sample solution to all reaction reagents without enzyme (AChE or $\mathrm{BChE}$ ). The samples and blank absorbances were read at $405 \mathrm{~nm}$ after 10 minutes of incubation at $25^{\circ} \mathrm{C}\left( \pm 1^{\circ} \mathrm{C}\right)$. The blank sample absorbance was subtracted from the sample, and the cholinesterase inhibitory activity was calculated according to the following equation:

$$
I(\%)=\frac{\left(A_{0}-A_{1}\right)}{A_{0}} \cdot 100
$$

where $A_{0}$ is the absorbance of the control, and $A_{1}$ is the absorbance of the extract/standard (galanthamine).

\section{Tyrosinase inbibition}

Tyrosinase inhibitory activity was measured using the modified dopachrome method with L-3,4dihydroxyphenylalanine (L-DOPA) as substrate (Zengin et al., 2014 ) with slight modifications. Sample solution ( $2 \mathrm{mg} / \mathrm{mL}, 25$ $\mu \mathrm{L})$ was mixed with tyrosinase solution $(200 \mathrm{u} / \mathrm{mL}, 40 \mu \mathrm{L})$ and phosphate buffer $(100 \mu \mathrm{L}, \mathrm{pH} 6.8)$ in a 96-well microplate, and then incubated for 15 minutes at $25^{\circ} \mathrm{C}\left( \pm 1^{\circ} \mathrm{C}\right)$. The reaction was started with the addition of L-DOPA $(40 \mu \mathrm{L})$. Similarly, a blank sample was prepared by adding sample solution to all reaction reagents without enzyme (tyrosinase). The samples and blank absorbances were read at $492 \mathrm{~nm}$ after 10 minutes of incubation at $25^{\circ} \mathrm{C}\left( \pm 1^{\circ} \mathrm{C}\right)$. Kojic acid $(0.1 \mathrm{mg} / \mathrm{mL})$ was used as a reference standard. The blank sample absorbance was subtracted from the sample, and the results were reported as percentage inhibition and calculated according to (1) (Table 2).

\section{a-Amylase inbibition}

The $\alpha$-amylase inhibitory activity was performed using Caraway-Somogyi iodine/potassium iodide (IKI) method (Zengin et al., 2014) with slight modifications. Sample solutions $(2 \mathrm{mg} / \mathrm{mL}, 25 \mu \mathrm{L})$ were mixed with $\alpha$-amylase solution $(10$ $\mathrm{u} / \mathrm{mL}, 50 \mu \mathrm{L})$ in phosphate buffer $(\mathrm{pH}$ 6.9, $6 \mathrm{mM}$ sodium chloride) in a 96-well microplate and incubated for 10 minutes 
Table 1. Total bioactive components of the different solvent extracts of Centaurea species

\begin{tabular}{|c|c|c|c|c|}
\hline Extracts & Species & $\begin{array}{c}\text { Total phenolics } \\
(\text { mg GAEs } / \text { g extract })^{1}\end{array}$ & $\begin{array}{c}\text { Total flavonoids } \\
{\text { (mg REs/g extract })^{2}}^{\text {(mg Re }}\end{array}$ & $\begin{array}{l}\text { Total condensed tannins } \\
(\mathrm{mg} \mathrm{CEs} / \mathrm{g} \text { extract })^{3}\end{array}$ \\
\hline \multirow{8}{*}{ Ethyl acetate } & C. depressa & $60.66 \pm 8.07^{\mathrm{c}}$ & nd & $7.95 \pm 2.48^{c}$ \\
\hline & C. drabifolia subsp. detonsa & $67.60 \pm 1.48^{\mathrm{c}}$ & $16.61 \pm 0.13^{\mathrm{b}}$ & $15.64 \pm 0.65^{\mathrm{b}, \mathrm{c}}$ \\
\hline & C. kotschyi var. persica & $98.74 \pm 0.31^{\mathrm{a}}$ & $5.76 \pm 1.65^{\mathrm{c}}$ & $7.88 \pm 0.86^{c}$ \\
\hline & C.patula & $81.00 \pm 0.17^{\mathrm{b}}$ & nd & $41.15 \pm 1.18^{\mathrm{a}}$ \\
\hline & C.pulchella & $48.07 \pm 2.31^{\mathrm{d}}$ & nd & $18.46 \pm 2.91^{\mathrm{b}}$ \\
\hline & C. tchihacheffii & $83.65 \pm 0.01^{\mathrm{b}}$ & $3.06 \pm 0.55^{\mathrm{d}}$ & $22.57 \pm 2.69^{\mathrm{b}}$ \\
\hline & C. triumfettii & $90.29 \pm 0.65^{\mathrm{a}, \mathrm{b}}$ & nd & $22.95 \pm 1.51^{\mathrm{b}}$ \\
\hline & C. urvillei subsp. hayekiana & $100.22 \pm 1.44^{\mathrm{a}}$ & $25.57 \pm 0.51^{a}$ & $20.90 \pm 3.34^{\mathrm{b}}$ \\
\hline \multirow{8}{*}{ Chloroform } & C. depressa & $88.77 \pm 0.70^{c}$ & nd & $24.63 \pm 1.08^{c}$ \\
\hline & C. drabifolia subsp. detonsa & $58.40 \pm 0.52^{\mathrm{e}}$ & $1.48 \pm 1.02^{\mathrm{c}}$ & $49.22 \pm 2.91^{\mathrm{a}}$ \\
\hline & C. kotschyi var. persica & $104.64 \pm 0.70^{\mathrm{b}}$ & nd & $26.08 \pm 0.11^{\mathrm{c}}$ \\
\hline & C.patula & $91.46 \pm 0.92^{c}$ & $1.87 \pm 0.47^{\mathrm{c}}$ & $15.80 \pm 2.58^{\mathrm{d}}$ \\
\hline & C. pulchella & $119.23 \pm 1.44^{\mathrm{a}}$ & nd & $34.76 \pm 0.75^{b}$ \\
\hline & C. tchibacheffii & $80.47 \pm 1.18^{\mathrm{d}}$ & nd & $17.17 \pm 0.43^{\mathrm{d}}$ \\
\hline & C. triumfettii & $43.19 \pm 1.79^{f}$ & $6.33 \pm 1.78^{b}$ & $15.26 \pm 2.69^{d}$ \\
\hline & C. urvillei subsp. hayekiana & $27.36 \pm 0.09^{\mathrm{g}}$ & $18.92 \pm 0.68^{a}$ & $5.36 \pm 0.97^{\mathrm{e}}$ \\
\hline
\end{tabular}

Data represent mean values \pm standard deviation $(\mathrm{n}=3)$. In the same extract, data marked with different letters indicate significant difference $(\mathrm{p}<0.05)$.

${ }^{1} \mathrm{GAEs}$, gallic acid equivalents; ${ }^{2} \mathrm{REs}$, rutin equivalents; ${ }^{3} \mathrm{CEs}$, catechin equivalents; nd $=$ not detected.

Table 2. Enzyme inhibitory activities of the different solvent extracts of Centaurea species (\%)

\begin{tabular}{|c|c|c|c|c|c|c|}
\hline \multirow{2}{*}{ Extracts } & \multirow{2}{*}{ Species } & Acetylcholinesterase & Butyrylcholinesterase & Tyrosinase & $\alpha$-Amylase & $\alpha$-Glucosidase \\
\hline & & \multicolumn{5}{|c|}{ ( $2 \mathrm{mg} / \mathrm{mL}$ concentration level) } \\
\hline \multirow{8}{*}{$\begin{array}{c}\text { Ethyl } \\
\text { acetate }\end{array}$} & C. depressa & $67.79 \pm 2.39^{\mathrm{b}, \mathrm{c}}$ & $49.15 \pm 0.42^{\mathrm{b}, \mathrm{c}}$ & $9.45 \pm 1.28^{c}$ & $36.93 \pm 0.97^{b}$ & $46.11 \pm 0.97^{c}$ \\
\hline & C. drabifolia subsp. detonsa & $69.14 \pm 0.09^{\mathrm{a}, \mathrm{b}, \mathrm{c}}$ & $82.23 \pm 0.48^{\mathrm{a}}$ & $15.53 \pm 0.23^{\mathrm{a}}$ & $25.58 \pm 0.38^{\mathrm{d}}$ & $43.10 \pm 2.41^{c}$ \\
\hline & C. kotschyi var. persica & $72.18 \pm 2.61^{\mathrm{a}, \mathrm{b}, \mathrm{c}}$ & $59.31 \pm 5.74^{\mathrm{b}}$ & $11.53 \pm 0.45^{\mathrm{a}, \mathrm{b}, \mathrm{c}}$ & $36.16 \pm 0.13^{b}$ & $42.35 \pm 2.22^{c}$ \\
\hline & C.patula & $68.61 \pm 0.09^{\mathrm{b}, \mathrm{c}}$ & $51.48 \pm 0.80^{\mathrm{b}, \mathrm{c}}$ & $15.21 \pm 2.04^{\mathrm{a}, \mathrm{b}}$ & $31.70 \pm 0.04^{\mathrm{c}}$ & $54.88 \pm 1.11^{\mathrm{b}}$ \\
\hline & C.pulchella & $73.76 \pm 1.87^{\mathrm{a}, \mathrm{b}}$ & $56.36 \pm 5.92^{\mathrm{b}, \mathrm{c}}$ & $9.39 \pm 0.01^{\mathrm{c}}$ & $21.54 \pm 0.04^{\mathrm{e}}$ & $35.59 \pm 0.58^{\mathrm{d}}$ \\
\hline & C. tchibacheffii & $66.53 \pm 1.14^{c}$ & $46.70 \pm 0.16^{c}$ & $11.26 \pm 1.43^{\mathrm{b}, \mathrm{c}}$ & $29.89 \pm 1.01^{\mathrm{c}}$ & $58.23 \pm 0.53^{b}$ \\
\hline & C. triumfettii & $70.15 \pm 0.57^{\mathrm{a}, \mathrm{b}, \mathrm{c}}$ & $50.11 \pm 0.05^{\mathrm{b}, \mathrm{c}}$ & $11.15 \pm 0.23^{\mathrm{b}, \mathrm{c}}$ & $42.84 \pm 0.34^{\mathrm{a}}$ & $69.88 \pm 1.16^{\mathrm{a}}$ \\
\hline & C. urvillei subsp. hayekiana & $76.08 \pm 2.91^{\mathrm{a}}$ & $85.23 \pm 0.72^{\mathrm{a}}$ & $10.73 \pm 0.98^{c}$ & $43.20 \pm 0.59^{\mathrm{a}}$ & $67.66 \pm 0.05^{\mathrm{a}}$ \\
\hline \multirow{8}{*}{ Chloroform } & C. depressa & $67.27 \pm 1.79^{d}$ & $70.75 \pm 2.60^{b}$ & $12.54 \pm 0.08^{\mathrm{a}}$ & $43.97 \pm 0.92^{b}$ & $53.45 \pm 1.98^{\mathrm{b}, \mathrm{c}}$ \\
\hline & C. drabifolia subsp. detonsa & $68.88 \pm 0.09^{\mathrm{d}}$ & $58.14 \pm 0.80^{\mathrm{d}}$ & $10.09 \pm 1.43^{\mathrm{a}}$ & $25.28 \pm 0.38^{e}$ & $36.03 \pm 0.24^{\mathrm{e}}$ \\
\hline & C. kotschyi var. persica & $76.98 \pm 0.01^{\mathrm{b}}$ & $69.90 \pm 1.99^{\mathrm{b}}$ & $10.67 \pm 0.15^{\mathrm{a}}$ & $42.72 \pm 0.17^{\mathrm{b}}$ & $49.42 \pm 0.92^{\mathrm{c}}$ \\
\hline & C.patula & $71.95 \pm 0.09^{c}$ & $66.89 \pm 0.64^{b, c}$ & $1.28 \pm 1.06^{c}$ & $33.30 \pm 0.04^{\mathrm{d}}$ & $56.11 \pm 0.24^{\mathrm{a}, \mathrm{b}}$ \\
\hline & C.pulchella & $95.93 \pm 0.07^{\mathrm{a}}$ & $95.69 \pm 0.06^{\mathrm{a}}$ & $4.54 \pm 0.68^{\mathrm{b}}$ & $59.54 \pm 0.59^{\mathrm{a}}$ & $60.31 \pm 2.13^{\mathrm{a}}$ \\
\hline & C. tchibacheffii & $72.29 \pm 0.38^{c}$ & $49.58 \pm 0.16^{\mathrm{e}}$ & $0.91 \pm 0.08^{c}$ & $40.26 \pm 0.29^{c}$ & $53.45 \pm 1.40^{\mathrm{b}, \mathrm{c}}$ \\
\hline & C. triumfettii & $60.04 \pm 0.09^{\mathrm{e}}$ & $63.37 \pm 0.37^{\mathrm{c}, \mathrm{d}}$ & $4.32 \pm 0.38^{b}$ & $22.40 \pm 0.17^{f}$ & $41.12 \pm 0.77^{\mathrm{d}}$ \\
\hline & C. urvillei subsp. hayekiana & $72.65 \pm 0.30^{c}$ & $43.94 \pm 1.51^{\mathrm{g}}$ & na & $17.53 \pm 0.08^{\mathrm{g}}$ & $43.65 \pm 0.39^{d}$ \\
\hline \multirow{3}{*}{$\begin{array}{l}\text { Reference } \\
\text { Standards }\end{array}$} & Galanthamine $(5 \mu \mathrm{g} / \mathrm{mL})$ & $78.56 \pm 1.05$ & $40.87 \pm 1.55$ & - & - & - \\
\hline & Kojic acid $(0.1 \mathrm{mg} / \mathrm{mL})$ & - & - & $59.34 \pm 0.60$ & - & - \\
\hline & Acarbose $(1 \mathrm{mg} / \mathrm{mL})$ & - & - & - & $50.51 \pm 0.25$ & $44.16 \pm 0.34$ \\
\hline
\end{tabular}

Data represent mean values \pm standard deviation $(\mathrm{n}=3)$. In the same extract, data marked with different letters indicate significant difference $(\mathrm{p}<0.05)$; na $=$ not active.

at $37^{\circ} \mathrm{C}\left( \pm 1{ }^{\circ} \mathrm{C}\right)$. After pre-incubation, the reaction was started by the addition of starch solution $(50 \mu \mathrm{L}, 0.05 \%)$. Similarly, blank samples were prepared by adding sample solution to all reaction reagents without the enzyme. The reaction mixture were incubated 10 minutes at $37^{\circ} \mathrm{C}\left( \pm 1^{\circ} \mathrm{C}\right)$. The reaction was then stopped with the addition of $\mathrm{HCl}(25$ $\mu \mathrm{L}, 1 \mathrm{M})$ followed by iodine-potassium iodide solution addition $(100 \mu \mathrm{L})$. The samples and blank absorbances were read at 630 $\mathrm{nm}$. Acarbose $(1 \mathrm{mg} / \mathrm{mL})$ was used as a reference standard. The blank sample absorbance was subtracted from the sample, and the results were reported as percentage inhibition and calculated according to (1).

\section{$\alpha$-Glucosidase inhibition}

The $\alpha$-glucosidase inhibitory activity was performed accordingly to a previous published method (Zengin et al., 2014) with slight modification. Sample solution $(2 \mathrm{mg} / \mathrm{mL}, 50 \mu \mathrm{L})$ were mixed with glutathione $(50 \mu \mathrm{L}), \alpha$-glucosidase solution $(0.4 \mathrm{u} / \mathrm{mL}$, $50 \mu \mathrm{L}$ ) in phosphate buffer ( $\mathrm{pH}$ 6.8) and $p$-nitrophenyl- $\beta$ - $\mathrm{D}$ glucopyranoside (PNPG, $10 \mathrm{mM}, 50 \mu \mathrm{L}$ ) in a 96-well microplate and incubated for 15 minutes at $37^{\circ} \mathrm{C}\left( \pm 1{ }^{\circ} \mathrm{C}\right)$. Similarly, blank samples were prepared by adding sample solutions to all reaction reagents without enzyme. The reaction was stopped with the addition of sodium carbonate $(50 \mu \mathrm{L}, 0.2 \mathrm{M})$. The sample and blank absorbances were read at $400 \mathrm{~nm}$. Acarbose was used as a reference standard $(1 \mathrm{mg} / \mathrm{mL})$. The blank sample absorbance was subtracted from the sample and the results were reported as percentage inhibition and calculated according to (1) (Table 2). 


\section{Results and Discussion}

Total phenolics, flavonoids, and condensed tannins content

Phenolic compounds are important plants secondary metabolites and have remarkable biological activities such as antioxidant, anti-carcinogenic and anti-inflammatory (Tsao, 2010). Hence, it is important to quantify phenolics content and to assess their contribution to enzyme inhibitory activity. Table 1 shows total phenolics, flavonoids and condensed tannins content of Centaurea extracts. The chloroform extract of $C$. pulchella had the highest total phenolics content (119.23 mg GAEs/g extract), followed by the ethyl acetate extracts of $C$. urvillei subsp. bayekiana, and $C$. kotschyi var. persica. These values are in accordance with those already reported in literature for other Centaurea species such as $C$. pulchella $(55.00 \mathrm{mg} \mathrm{GAEs} / \mathrm{g}$ extract by Zengin et al. (2010) and, $C$. antalyense (227.12 mg GAEs/g extract by Aktumsek et al. (2013)).

The total flavonoids content was measured using the aluminium chloride colorimetric assay. Among Centaurea samples, both ethyl acetate and chloroform extracts of $C$. urvillei subsp. hayekiana contained the highest concentration of flavonoids with 25.57 and $18.92 \mathrm{mg}$ REs/g extracts, respectively. However, the presence of flavonoids was not detectable in all Centaurea extracts (Table 1).

Regarding total condensed tannins content, the chloroform extract of $C$. drabifolia subsp. detonsa had the highest total condensed tannins content with a value of $49.22 \mathrm{mg} \mathrm{CEs} / \mathrm{g}$ extract, followed by the ethyl acetate extract of $C$. patula and the chloroform extract of C. pulchella (Table 1).

Ethyl acetate (polarity 6) and chloroform (polarity 4.8) were used in this work as extraction solvents in order to characterize the phenolics extraction yields in less polar solvents, as observed by Anwar et al. (2013). These authors reported that extraction yields tend to increase from water (polarity 80) to ethanol (polarity 24), while acetone (polarity 21) and methanol (polarity 33) present similar extraction yields.

\section{Enzyme inhibitory activities}

$\mathrm{AD}$ is a form of dementia, gradually and irreversibly evolving in a loss of memory and other mental abilities (Scarpini et al., 2003). Low levels of acetylcholine in synaptic cleft characterize $\mathrm{AD}$, and in this context, the cholinergic hypothesis is the most accepted strategy for the treatment of AD. Accordingly, the inhibition of cholinesterase, which catalyzes acetylcholine hydrolysis increase the level of acetylcholine in the brain (Murray et al., 2013).

The evaluation of cholinesterase inhibitors is one of the most important topics in pharmaceutical areas and, particularly, in medicinal chemistry. Most drugs commonly used for $\mathrm{AD}$ treatment are cholinesterase inhibitors, namely tacrine, galantamine and donezepil. However, they present several side effects such as gastrointestinal disorders (Chopra et al., 2011). In this context, the discovery of new, safe, effective, and naturally occurring cholinesterase inhibitors from plants might be an important strategy for the management of symptoms associated with AD.

In this work, the anticholinesterase activities of Centaurea extracts were investigated using Ellman's spectrophotometric method and the results are depicted in Table 2 . The chloroform extract of $C$. pulchella exhibited the highest inhibitory activity against both $\mathrm{AChE}$ and $\mathrm{BChE}$. This extract had excellent inhibition value on $\mathrm{AChE} \mathrm{(95.93 \% )} \mathrm{and} \mathrm{BChE} \mathrm{(95.69 \% )} \mathrm{at} \mathrm{the}$ concentration of $2 \mathrm{mg} / \mathrm{mL}$, and had the highest level of phenolics amongst the studied samples. Therefore, phenolic components present in the extract might be responsible for the observed anticholinesterase activity. Several authors reported previously a strong relationship between phenolic content and anticholinesterase activity (Orhan et al., 2012; Hlila et al., 2015). Moreover, anticholinesterase activities of some Centaurea species such as $C$. antalyense, $C$. balsamita, $C$. iberica were also reported recently in literature (Aktumsek et al., 2013; Ertas et al., 2014).

The synthesis and spread use of melanin play a main role in skin color and pigmentation. Tyrosinase, a copper-containing mono-oxygenase, is a key enzyme in melanin biosynthesis (Kim and Uyama, 2005). Skin disorders such as scarce, melasma (facial pigmentation), and freckles are related to excessive melanin biosynthesis. Thus, tyrosinase inhibitors are used to control or treat pigmentation disorders, and are widely used in the cosmetic industry. In fact, some tyrosinase inhibitors such as kojic acid and hydroquinones are nowadays commercially produced, but they can present severe side effects for example skin inflammation (Loizzo et al., 2012). Hence, in recent years, more attention has been paid to the use of natural plant extracts as a safe and alternative source of tyrosinase inhibitors for cosmetic purposes.

Centaurea extracts had low tyrosinase inhibitory activities (0.91-15.53\%, at the concentration of $2 \mathrm{mg} / \mathrm{mL})$, as reported in Table 2. The ethyl acetate extract of $C$. drabifolia subsp. detonsa presented the highest tyrosinase inhibition, with a value of 15.53\%. Chloroform extract of C. urvillei subsp. hayekiana showed no inhibitory effect against tyrosinase. Additionally, chloroform extract of $C$. pulchella had the highest concentration of phenolics, but exhibited lower inhibitory effect on tyrosinase (4.54\%). This demonstrates that the phenolic compounds from the tested Centaurea samples have none or low inhibitory effects.

$\mathrm{DM}$ is one of the most common metabolic diseases and is characterized by insulin secretion problems and defects of carbohydrate, lipid, and protein metabolism. Thus, type $2 \mathrm{DM}$ is generally associated with chronic hyperglycemia. For this reason, the decrease of high blood glucose level is an important factor in development of DM. Two enzymes, namely $\alpha$-amylase and $\alpha$ glucosidase, are involved in the hydrolysis of starch and oligosaccharides increasing considerably blood glucose levels. In this sense, amylase and/or glucosidase inhibitors are valuable agents in the treatment and management of hyperglycemia (Exteberria et al., 2012). Synthetic inhibitors, such as acarbose, are widely used as oral anti-diabetic drugs. Nevertheless, they also cause side effects including diarrhea and flatulence (Dong et al., 2012; Saha and Verma, 2012).

$\alpha$-amylase and $\alpha$-glucosidase inhibitory effects of Centaurea extracts are shown in Table 2.

All Centaurea extracts were able to inhibit the activity of both enzymes at the concentration of $2 \mathrm{mg} / \mathrm{mL}$ (Table 2). Regarding $\alpha$-amylase inhibitory effects, the chloroform extract of C. pulchella was the most active (59.54\%) followed by the chloroform extract of $C$. depressa (43.97\%) and the ethyl acetate extract of $C$. urvillei subsp. hayekiana (43.20\%). As observed for the anti-glucosidase effect, the ranked order of inhibition was: ethyl acetate extract of $C$. triumfetti $(69.88 \%)>$ ethyl acetate extract of $C$. urvillei subsp. hayekiana $(67.66 \%)>$ chloroform extract of $C$. pulchella (60.31\%). However, acarbose (50.51\% for $\alpha$-amylase and $44.16 \%$ for $\alpha$-glucosidase) showed the highest 
inhibitory effect already at $1 \mathrm{mg} / \mathrm{mL}$ in comparison to the other herein studied Centaurea extracts.

\section{Conclusions}

Based on the reported inhibition activities and biologically active compounds (phenolics, flavonoids and condensed tannins), Centaurea species can be considered as a valuable starting point in the development of new bioactive formulations or dietary supplements that can support the biological effects of a "classical" therapy for $\mathrm{AD}$ or $\mathrm{DM}$ disease without the adverse effects generally observed for synthetic drugs. Moreover, evidence that anticholinesterase, $\alpha$-amylase and $\alpha$-glucosidase inhibitory activities might be related with the total phenolics content in the studied extracts studied was shown. To the best of our knowledge, this is the first report of the in vitro anticholinesterase, tyrosinase, $\alpha$-amylase and $\alpha$-glucosidase inhibitory effects of the studied Centaurea species. However, further investigations are necessary in order to elucidate the mechanisms of the in vivo pharmacological activities, bioavailability and involved metabolic pathways.

\section{Acknowledgments}

The authors gratefully acknowledge the financial support given for this research from the Selcuk University.

\section{References}

Aktumsek A, Zengin G, Guler GO, Cakmak YS, Duran A (2013). Antioxidant potentials and anticholinesterase activities of methanolic and aqueous extracts of three endemic Centaurea L. species. Food and Chemical Toxicology 55:290-296.

Anwar F, Kalsoom U, Sultana B, Mushtaq M, Mehmood T, Arshad HA (2013). Effect of drying method and extraction solvent on the total phenolics and antioxidant activity of cauliflower (Brassica oleracea L.) extracts. International Food Research Journal 20:653-659.

Bekir J, Mars M, Souchard JP, Bouajila J (2013). Assessment of antioxidant, antiinflammatory, anti-cholinesterase and cytotoxic activities of pomegranate (Punica granatum) leaves. Food and Chemical Toxicology 55:470-475.

Berk S, Tepe B, Arslan S, Sarikurkcu C (2011). Screening of the antioxidant, antimicrobial and DNA damage protection potentials of the aqueous extract of Asplenium ceterach DC. African Journal of Biotechnology 10:8902-8908.

Carradori S, D’Ascenzio M, Chimenti P, Secci D, Bolasco A (2014). Selective MAO-B inhibitors: a lesson from natural products. Molecular Diversity 18:219-243.

Chopra K, Misra S, Kuhad A (2011). Current perspectives on pharmacotherapy of Alzheimer's. Expert Opinion on Pharmacotherapy 12:335-350.

Davis PH (1988). Flora of Turkey and the East Aegean Islands, Vol. 10, Edinburgh, Edinburgh University Press.

De Monte C, Carradori S, Chimenti P, Secci D, Mannia L, Alcaro F, Petzer A, N’D, CI, Gidaro MC, Costa G, Alcaro S, Petzer JP (2014). New insights into the biological properties of Crocus sativus L.: chemical modifications, human monoamine oxidases inhibition and molecular modelling studies. European Journal of Medicinal Chemistry 82:164 171.

De Monte C, Bizzarri B, Gidaro MC, Carradori S, Mollica A, Luisi G, Granese A, Alcaro S, Costa G, Basilico N, Parapini S, Scaltrito MM, Masia C, Sisto F (2015) Bioactive compounds of Crocus sativus L. and their semi-synthetic derivatives as promising anti-Helicobacter pylori, antimalarial and anti-leishmanial agents. Journal of Enzyme Inhibition and Medicinal Chemistry 30:1027-1033.

Dong HQ, Li M, Zhu F, Liu FL, Huang JB (2012). Inhibitory potential of trilobatin from Lithocarpus polystachyus Rehd against $\alpha$-glucosidase and $\alpha$-amylase linked to type 2 diabetes. Food Chemistry 130:261-266.

Ertas A, Gören AC, Boga M, Demirci S, Kolak U (2014). Chemical composition of the essential oils of three Centaurea Species growing wild in Anatolia and their anticholinesterase activities. Journal Essential Oil Bearing Plants 17:922-926.

Etxeberria U, De la Garza AL, Campión J, MartínezJA, Milagro FI (2012). Antidiabetic effects of natural plant extracts via inhibition of carbohydrate hydrolysis enzymes with emphasis on pancreatic alpha amylase. Expert Opinion on Therapeutic Targets 16:269-297.

Garcia-Jacas N, Susanna A, Mozaffarian V, Ilarslan R (2000). The natural delimitation of Centaurea (Asteraceae: Cardueae): ITS sequence analysis of the Centaurea jacea group. Plant Systematics and Evolution 223:185-199.

Genovese S, Epifano F, Carlucci G, Marcotullio MC, Curini M, Locatelli M (2010). Quantification of 4'-geranyloxyferulic acid, a new natural colon cancer chemopreventive agent, by HPLC-DAD in grapefruit skin extract. Journal of Pharmaceutical and Biomedical Analysis 53:212214.

Gidaro MC, Alcaro F, Carradori S, Costa G, Vullo D, Supuran CT, Alcaro $S$ (2015) Eriocitrin and apigenin as new carbonic anhydrase VA inhibitors, from a virtual screening of Calabrian natural products. Planta Medica 81:533-540.

Hlila MB, Mosbah H, Mssada K, Jannet HB, Aouni M, Selmi B (2015). Acetylcholinesterase inhibitory and antioxidant properties of roots extracts from the Tunisian Scabiosa arenaria Forssk. Industrial Crops and Products 67:62-69.

Jemia MB, Formisano C, Bancheva S, Bruno M, Senatore F (2012). Chemical composition of the essential oils of Centaurea formanekii and C. orphanidea ssp. thessala, growing wild in Greece. Natural Product Communications 7:1083-1086.

Karamenderes C, Khan S, Tekwani BL, Jacob MR, Khan IA (2006). Antiprotozoal and antimicrobial activities of Centaurea Species Growing in Turkey.Pharmaceutical Biology 44:534539.

Kim YJ, Uyama H (2005). Tyrosinase inhibitors from natural and synthetic sources: structure, inhibition mechanism and perspective for the future. Cellular and Molecular Life Sciences 62:1707-1723.

Khoddami A, Wilkes MA, Roberts TH (2013). Techniques for analysis of plant phenolic compounds. Molecules 18:2328-2375.

Kumar D, Gupta N, Ghosh R, Gaonkar RH, Pal BC (2013). $\alpha$-Glucosidase and $\alpha$-amylase inhibitory constituent of Carex baccans: Bio-assay guided isolation and quantification by validated RP-HPLC-DAD. Journal of Functional Foods 5:211-218. 
200

Locatelli M, Epifano F, Genovese S, Carlucci G, Končić MZ, Kosalec I, Kremer D (2011). Anthraquinone profile, antioxidant and antimicrobial properties of bark extracts of Rhamnus catharticus and $R$. orbiculatus. Natural Product Communications 6:1275-1280.

Locatelli M, Genovese S, Carlucci G, Kremer D, Randic M, Epifano F (2012b). Development and application of high-performance liquid chromatography for the study of two new oxyprenylated anthraquinones produced by Rhamnus species. Journal of Chromatography A 1225:113-120.

Locatelli M, Governatori L, Carlucci G, Genovese S, Mollica A, Epifano F (2012a).Recent application of analytical methods to phase I and phase II drugs development: a review. Biomedical Chromatography 26:283300.

Loizzo MR, Tundis R, Menichini F (2012). Natural and synthetic tyrosinase inhibitors as antibrowning agents: an update. Comprehensive Reviews in Food Science and Food Safety 11:378-398.

Magio A, Riccobono L, Bancheva S, Bruno M, Senatore F (2014). Chemical composition of the essential oil of the local endemics Centaurea davidovii and C. parilica (Asteraceae, sect. Lepteranthus) from Bulgaria. Natural Product Communications 9:1373-1376.

Mukherjee PK, Kumar V, Mal M, Houghton PJ (2007). Acetylcholinesterase inhibitorsfrom plants. Phytomedicine 14:289-300.

Murray AP, Faraoni MB, Castro MJ, Alza NP, Cavallaro V (2013). Natural AChE inhibitors from plants and their contribution to Alzheimer's disease therapy. Current Neuropharmacology 11:388-413.

Orhan IE, Erdem SA, Senol FS, Kartal M, Sener B (2012). Exploration of cholinesterase and tyrosinase inhibitory, antiprotozoal and antioxidant effects of Buxus sempervirens L. (boxwood). Industrial Crops and Products 40:116-121.

Orhan I, Şener B, Choudhary MI, Khalid A (2004). Acetylcholinesterase and butyrylcholinesterase inhibitory activity of some Turkish medicinal plants.Journal of Ethnopharmacology 91:57-60.

Pan SY, Zhou SF, Gao SH, Yu ZL, Zhang SF, Tang MK, Ko KM (2013). New perspectives on how to discover drugs from herbal medicines: CAM's outstanding contribution to modern therapeutics. EvidenceBased Complementary and Alternative Medicine 2013:1-25
Saha S, Verma R (2012). Inhibitory potential of traditional herbs on $\alpha$ amylase activity. Pharmaceutical Biology 50:326-331.

Scarpini E, Scheltens P, Feldman H (2003) Treatment of Alzheimer's disease: current status and new perspectives. Lancet Neurology 2:539547.

Shoeb M, Jaspars M, MacManus SM, Celik S, Nahar L, Kong-Thoo-Lin P, Sarker SD (2007). Anti-colon cancer potential of phenolic compounds from the aerial parts of Centaurrea gigantea (Asteraceae). Journal of Natural Medicines 61:164169.

Slinkard K, Singleton VL (1977). Total phenol analyses: automation and comparison with manual methods. American Journal of Enology and Viticulture 28:49-55.

Tsao R (2010). Chemistry and biochemistry of dietary polyphenols. Nutrients 2:1231-1246.

Tundis R, Menichini F, Loizzo MR, Bonesi M, Solimene U, Menichini F (2012). Studies on the potential antioxidant properties of Senecio stabianus Lacaita (Asteraceea) and its inhibitory activity against carbohydrate-hydrolysing enzymes. Natural Product Research 26: 393404.

Zengin G, Locatelli M, Ceylan R, Aktumsek A (2015). Anthraquinone profile, antioxidant and enzyme inhibitory effect of root extracts of eight Asphodeline taxa from Turkey: "Can Asphodeline roots be considered as a new source of natural compounds?"; Journal of Enzyme Inhibition and Medicinal Chemistry Doi: 10.3109/14756366.2015.1063623.

Zengin G, Cakmak YS, Guler GO, Aktumsek A (2010). In vitro antioxidant capacities and fatty acid compositions of three Centaurea species collected from Central Anatolia region of Turkey. Food and Chemical Toxicology 48:2638-2641.

Zengin G, Uysal A, GunesE, Aktumsek A (2014). Survey of phytochemical composition and biological effects of three extracts from a wild plant (Cotoneaster nummularia Fisch. et Mey.): A Potential Source for Functional Food Ingredients and DrugFormulations. Plos One 9:1-13. 